Pataki János István

\title{
A végrehajtás és a behajtás a rendőri eljárás tükrében
}

\section{Execution and exaction reflected upon police procedure}

\begin{abstract}
Absztrakt
A Szegedi Rendészeti Szakgimnázium alapfeladata a rendőrség végrehajtó állományának nappali rendszerủ oktatás keretében történő képzése. Természetesen ezen feladat mellett számos olyan tanfolyamot, tréninget, továbbképzést folytatunk, amely hozzájárul a végrehajtásban dolgozók ismereteinek naprakészen tartásához. A 2018-tól iskolánk szervezésében folyik a dél-alföldi régióban dolgozó alosztályvezetők továbbképzése, amely képzés az elmúlt időszak visszajelzései alapján sikeres és népszerủ az érintett munkatársak körében. Iskolánk mindig figyelmet fordított arra, hogy a kötelezö tananyagon kívül valamilyen aktuális, az adott kérdést több oldalról megvilágító, gyakorlatias ismereteket is nyújtson a képzésben résztvevőknek. A médiában gyakran látunk olyan képeket, amelyeken a bírósági végrehajtás eredményes megvalósítása érdekében rendőri segítséget vesznek igénybe. A társadalom szempontjából ez rendkívül megosztó is lehet, és teljesen nyilvánvaló, hogy az ebben résztvevő munkatársainknak sem ez a legkedvesebb rendőri feladat. Ezt megfelelő higgadtsággal kell kezelni és alapos felkészülést igényel minden résztvevő számára. Ezt hivatott segíteni a következő oldalakon található összefoglaló, amelyet egy előadás keretében a bünügy és a közrendvédelem területén dolgozó alosztályvezetők a képzés keretein belül meghallgathattak jelen sorok szerzőjének előadásában. ${ }^{1}$
\end{abstract}

Kulcsszavak: végrehajtás, behajtás, rendőrség

\section{Abstract}

The basic task of the Law Enforcement Secondary School Szeged is the education of the executive staff of police in a day school. We further organize a lot

Az előszót Dr. Bardócz Csaba r. ezredes, rendőrségi főtanácsos a Szegedi Rendészeti Szakgimnázium igazgatója írta. 
of courses and trainings helping the executive staff to up-to-date knowledge. Our school has organized since 2018 trainings for subdivision leaders in the South Plain Region of Hungary, which is due to feedbacks of the past period successful and popular for the participating colleagues. Our school has always paid attention to offer beside the obligatory curriculum also actual and practical knowledge for the participants. In the media can be frequently seen that the help of police is demanded for a successful fulfilment of execution ordered by court.

This might be very divisive for the society and is obviously not the most preferred work for the police colleagues involved. This must be fulfilled with appropriate temperateness and needs a suitable preparation for each of the participants. This should be supported by the summary on the following pages, about that the participating subdivision leaders of detective squad and of public order were informed in frame of a lecture held by the author of this article.

Keywords: execution, exaction, police

\section{Bevezetés}

Napjainkban, mint az közismert tény, a magyar lakosság kötelezettségvállalási, hitelfelvételi hajlandósága megnőtt ${ }^{2}$, ugyanakkor a kötelezettségek darabszámának növekedése már ab ovo önmagában is azt a fenyegetettséget hordozza, hogy az önkéntes jogkövető magatartási formák, a nem fizetett hitelek, kölcsönök, kötelezettségek (a továbbiakban együtt: hitelek) aránya is megnövekszik. A hitel felvevőjének részéről az önkéntes jogkövető magatartás elmaradása a hitelezői oldalon jórészt valamilyen szerződés, illetve szerződéses biztosíték alapján teljesítetlen követelést eredményez, amelynek következtében ezek a kötelezettségvállalást magukban foglaló szerződések felmondásra kerülhetnek. Az így kialakuló követeléseket a hitelezők - a kötelezettől be- vagy végrehajtás útján az önkéntes jogkövető magatartás kikényszerítésével - megkísérlik érvényesíteni, hogy követelésállományuk csökkenjen.

A növekvő ügydarabszám és a növekvő követelésállomány okán már közvetlen és belátható módon is megnövekszik a helyszíni be-, illetve végrehajtási cselekmények száma, és a helyszíni cselekmények darabszámának növekedése megnöveli a helyszínen kialakult konfliktusok számát is (hiszen a hitelező és

2 Központi Statisztikai Hivatal: Lakossági lakáshitelezés, 2018. In: Statisztikai Tükör. Budapest, 2019. 1. o. 2018. december 31-én a lakáshitel-állomány 3324 milliárd forint volt, 10,3\%-kal (309 milliárd forinttal) nagyobb a 2017. véginél, miközben a GDP-hez viszonyított aránya az egy évvel korábbival megegyező maradt $(7,9 \%)$ az adós között antagonisztikus ellentét alakul ki), ezáltal természetesen megnövekszik a helyszíni rendőri intézkedések, eljárások száma is.

\section{Különbségtétel}

Alapvetően két különálló tevékenységről beszélhetünk. Egyrészt a végrehajtásról, amely alatt az önálló bírósági végrehajtó (a továbbiakban: ÖBV) által a bíróság hatáskörében ${ }^{3}$ lefojtatott eljárási cselekményeket értjük, másrészt pedig a követeléskezelésről, az úgynevezett behajtásról, amely alatt különböző követeléskezeléssel is foglalkozó gazdasági társaságok, de akár természetes személyek által végzett követeléskezelési, behajtási tevékenységről beszélhetünk. A végrehajtás-behajtás fogalom-ellentétpárral jellemezhető a legjobban, és a legrelevánsabb módon a hétköznapi életben tapasztalható egyik legfajsúlyosabb és leggyakrabban felvetődő probléma, illetve félreértés a kétféle eljárás kapcsán. (Pataki, 2014a) A mindennapok gyakorlata során sok esetben nem tisztázott az, hogy eleve két, alapvetően különböző tevékenységről és ezáltal két teljesen más fogalomról van szó. Nem lehet összekeverni a két önálló fogalmat, valamint meg kell különböztetni a végrehajtás és a behajtás által takart tartalmi, illetve realizációs elemeket. Ezt az elemi különbségtételt sok esetben az érintett felek fogalmi ismerethiánya okán a bejelentést felvevő, és rendőri intézkedést felvevőnek, illetve helyszíni intézkedést foganatosító rendőri állománynak kell megtennie. Mindkét fogalomhoz alapvetően más tényállási elemek kötődnek, és ezért a helyszíni intézkedést, a realizációt is alapvetően ez a fogalmi megkülönböztetés determinálja. Ergo a végrehajtás fogalom alatt jelen esetben a bírósági végrehajtást, mint jogintézményt, míg behajtás fogalom alatt az egyéb gazdasági társaságok vagy természetes személyek által végzett (tágan értelmezett) követeléskezelési, mint gazdasági tevékenységek elemeit érthetjük. Mindebből következően a rendőri helyszíni eljárások realizációját, az esetlegesen tapadó (büntető) tényállások vizsgálatát is a legjobban az elméleti fogalompár tagjainak elemzésén keresztül lehetséges értelmezni és elemezni.

3 1994. évi LIII. törvény a bírósági végrehajtásról

225. § (1) A végrehajtás elrendelését és foganatositását - e törvényben megállapított szabályok szerint a bíróság, illetve a közjegyző, továbbá e törvényben meghatározott más szervek és személyek, így különösen a következök végzik:

a) az önalló birósági végrehajto

c) az önálló bírósági végrehajtó-helyettes,

e) a végrehajtójelölt.

(2) A végrehajtó eljárása - mint polgári nemperes eljárás - a bíróság eljárásával azonos. 


\section{Bírósági végrehajtás}

Az állam számára egyfajta kötelezettségként (Frank, 1846) jelentkezik a jogvitákkal kapcsolatos döntések érvényre juttatása. Ennek a kötelezettségnek az egyik megvalósulási formája maga a bírósági végrehajtás intézménye. A bírósági végrehajtás a magánjog (civilisztika) területén realizált igazságszolgáltatás. (Pokol, 2000) Az emberi magatartásoknak meg kell felelniük a jogi normáknak, illetve az ezek alapján hozott, államilag elismert döntéseknek. A végrehajtás intézményrendszere a jogbiztonsággal szoros korrelációt képez. A jogbiztonság érvényesülésének elengedhetetlen feltétele, hogy a bíróság jogerős döntéseiben foglaltak végrehajtása önkéntes teljesítés hiányában is megtörténjen. (Pataki, 2013a; 2013b)

„A bírósági végrehajtás a vagyoni végrehajtás fö útja: az a viszonylag önálló - rendszerint más, jogvitát eldöntő eljáráshoz kapcsolódó - polgári nemperes eljárás, amelynek során a bíróság, illetőleg a birósági szerv általában vagyoni kényszerrel juttatja érvényre a kötelezettség teljesitésére vagy biztositására irányuló jogi szankciót”. (Vida, 1978.)

Magyarország Alaptörvénye - mint a jogrendszer alapja - is számos garanciális elemet tartalmaz a jogrendszerre, jogbiztonságra, a tulajdonhoz való jogra, a társadalmi felelősségre, mint alapvető jogelvekre nézve. Az Alaptörvény Alapvetés fejezet C) cikk (3) bekezdés rendelkezik az állami kényszer alkalmazásának jogáról, amely szerint ,Az Alaptörvény és a jogszabályok érvényre juttatása érdekében kényszer alkalmazására az állam jogosult." A bíróságok az Alaptörvény által deklaráltan igazságszolgáltatási tevékenységet látnak el (25. cikk (1) pont). Ezen a módon is láthatóvá válik, hogy az önálló hatósági végrehajtó által foganatosított eljárás a bíróság eljárásával azonos.

Tágan értelmezve tehát a legelemibb és legminimálisabb társadalmi kultúra kialakulása, a tulajdon, a közös tulajdon, a magántulajdon megjelenése óta beszélhetünk valamilyen végrehajtási (szokás)jogról, végtére is a tulajdon a mindenkori társadalmak egyik legelemibb intézménye (Harmathy, 1989; Téglási, 2008; Kovács, 1989), a végrehajtás és a tulajdon pedig ebből a kontextusból nézve elválaszthatatlan fogalompárt alkot. A jog abban a formájában, ahogyan ma ismerjük, a rómaiak találmánya, a jogtudomány pedig kimondottan az ókori Rómában született meg. (Földi-Hamza, 2007; Pataki, 2014b) A római jog fejlődésén keresztül látható, ahogyan az általánosan elfogadott erkölcsi normák átalakultak fokozatosan jogi normákká, amelyeket a római jog tekintetében a XII táblás törvénytől (Kr. e. V. század közepe) eredeztetünk. Egy csaknem háromezer éves (jog)intézményről beszélhetünk, amely a társadalmi változásokkal egy ütemben fejlödött.
Magyarországon már az I. Szent István király által kibocsátott dekrétumok második könyve is tartalmaz olyan rendelkezéseket, amelyek a végrehajtás jogához szorosan kapcsolódnak. „A mai értelemben vett birósági végrehajtás kialakulásának kezdeteit csak a XIX. század elsö felében fedezhetjük fel." (Vida, 1978.) Az első átfogó, teljes egészében önálló végrehajtási törvény az 1881. évi LX. törvénycikk a végrehajtási eljárást szabályozta, amely többek között már rendelkezett az árverés intézményéről. A törvény ismerte a biztosítási intézkedések fogalmát, az önálló pénzkövetelés fogalmát, az ingó-ingatlan bontást, a hirdetményt, a zárlatot stb. A végrehajtás alapjául végrehajtható közokirat szolgált. Az 1881. évi LX. törvénycikk a gazdasági élet jelentős változásainak köszönhetően több nagyobb módosításon és kiegészítésen esettát, de 1955-ig hatályban maradt. A II. világháború után, 1945-től a szocialista rendszer terminológiája szerint az 1955. évi 21. tvr. megjelenéséig több mint ötven olyan jogszabályt léptettek életbe, amelyek korlátozták vagy kizárták a bírósági végrehajtást. A rendszerváltozás és a piacgazdaságra történő átállás bebizonyította, hogy gyökeres módosításra van szükség a bírósági végrehajtási eljárások vonatkozásában. A szocialista rendszer időszakában meghonosodott szemléletmód nem volt tartható. Megszületett az 1994. évi LIII. törvény a bírósági végrehajtásról (a továbbiakban: Vht.), amely napjainkban is speciális jogszabályi keretrendszert biztosít a bírósági végrehajtás jogintézménye számára. ${ }^{4}$ Természetesen a Vht. napjainkig több jelentős módosításon esett át. A módosítások a bírósági végrehajtási eljárások eredményességét és hatékonyságát kívánták növelni az adós és a hitelezővédelem kényes egyensúlyát megtartva. Magának a bírósági végrehajtásnak a fogalmi jellegü meghatározására több definíciószerü megoldást találhatunk a szakirodalomban, de ezek csak megfogalmazásukban mások, értelmük, értelmezésük egyértelmüen egy irányba mutat. „A bírósági végrehajtás - mint nem peres eljárás - jogviszonyok összessége. A végrehajtás meginditása a végrehajtási jog meglététöl függ, amely az eredetileg érvényesitendöjoghoz kapcsolódik. A végrehajtási jog szükebb értelemben a végrehajtási eljárás meginditásának jogát, tágabb értelemben a jogviszony során keletkezö anyagi és eljárásjogi következmények összességét jelenti, amelyek a végrehajtási eljárásban részt vevők jogaiban és kötelezettségeiben bekövetkeznek." (Balogh és mtsai., 2009)

4 1994. évi LIII. törvény indokolása a bírósági végrehajtásról, Vht. kommentár, Általános indoklás fejezet (1)

A jog érvényesülését általában az önkéntes követés jellemzi, végsö soron azonban az állam kényszeritó ereje juttaja érvényre a jogot. llyen kényszeritó jellegú eljaras a birosagi végrehajtas is, amely nélk lozhetetlen ahhoz, hogy a birosagok és a jogvitat eldonto más szervek határozatait èrvényre juttassät e határozatokon, továbbá egyes okiratokon alapuló követeléseket az adósoktól behajtsák. Ezért a birrósági végrehajtás fontos szerepet tölt be az igazságszolgáltatás feladatainak megoldásában, a jogrendszer gyakorlati megvalósitásában. 
„A birósági végrehajtás olyan önálló, törvényileg szabályozott eljárás, amelyben állami, vagy meghatározott szempontból azzal azonosnak minösülö szerv, elsősorban vagyoni kényszeralkalmazása révén juttatja érvényre az állam által, a konkrét egyedi ügyben fennállónak elismert és kikényszerithető alanyi jogot, vagy elözetesen biztositja a konkrét egyedi ügyben történö elismerés vagy kikényszerithetöség elött védelemben részesitett alanyi jog későbbi érvényre jutását." (Kapa, 2006.)

Alapvetően két részre bonthatjuk magát a bírósági végrehajtási eljárást. Az első rész a végrehajtás elrendelésével foglalkozik, míg a második rész a végrehajtás foganatosításával. Az első szakaszhoz leginkább az eredetileg érvényesítendő jog kötődik, és ebben a stádiumban a végrehajtó személye még meg sem jelenik. A második szakaszhoz leginkább az állami kényszer megjelenése köthető - amennyiben az önkéntes teljesítés elmarad -, és az itt alkalmazott állami kényszert már a végrehajtó foganatosítja (egyes kényszercselekményeket a rendőrség szervezetének igénybevételével végez el, amennyiben arra szükség van). Az állami kényszer elsősorban az adós vagyona, vagy kivételesen személye ellen irányulhat. (Pataki, 2013a) Az elrendelési szakasz végeredményeként születik meg maga a követelés fennállását, és annak jogosságát igazoló, a követelés összegszerüségét jóváhagyó, a végrehajtás foganatosításának alapjául szolgáló okirat. Másként megfogalmazva megnyílik a végrehajtási jogcím. A második szakaszhoz, azaz a végrehajtás foganatosítási szakaszához leginkább az állami kényszer megjelenése köthető. Az itt alkalmazott állami kényszert már a végrehajtó foganatosítja a követelés jogszerüségének vizsgálata nélkül, hiszen az elrendelési szakasz egyik elemeként az már jogerős módon megállapításra került.

\section{A helyszíni eljárás, és a vonatkozó jogszabályi elemek}

Mindenekelött le kell szögezni, hogy a 2012. évi C. törvény a büntető törvénykönyvről (a továbbiakban Btk.) szerint az ÖBV az eljárása során hivatalos személynek minősül ${ }^{5}$ (kapcsolódó büncselekményi tényállások lehetnek: Btk. XXIX. fejezet, a hivatalos személy elleni büncselekmények, 310-312. §-ai). A Vht. alapján az ÖBV és az ÖBV helyettese közhatalmi feladatot lát el. Ebböl következően a Btk. hivatali büncselekmények (XV. fejezet, IV. cím), és a hivatalos személy elleni büncselekmények (XV. fejezet, V. cím) egyes szakaszai

5 2012. évi C. törvény a büntető törvénykönyvröl

459. § (1) 11. hivatalos személy: $\mathrm{h}$ ) az önálló bírósági végrehajto, az önálló bírósági végrehajtó-helyettes és a végrehajtói kézbesítésre felhatalmazott önálló bírósági végrehajtó jelölt. vonatkoznak az ÖBV személyére is. Az érdemi különbözőség, hogy a hivatali büncselekmények elkövetője lehet az ÖBV, míg a hivatalos személy elleni eröszak büncselekményeknek pedig a sértettje lehet.

A bírósági végrehajtás egyik dedikált célja az, hogy a bíróságok és a jogvitát eldöntő más szervek határozatainak, továbbá egyes okiratokon alapuló követeléseknek bírósági végrehajtás útján állami kényszerrel is érvényt kell szerezni. Az ÖBV egyik kötelezettségeként az eljárás foganatosítási szakaszában helyszíni eljárási cselekmény lebonyolítása válhat szükségessé. A helyszíni eljárás foganatosítása során az ÖBV jogosult a Vht. által tételesen meghatározott kényszerintézkedések megtételére. Az ÖBV a helyszínen tapasztaltak alapján saját mérlegelése szerint ítéli meg az alkalmazandó kényszerintézkedések szükségességét. Mindazon intézkedéseket alkalmazni fogja, amelyek szükségesek a helyszíni eljárás céljának eléréséhez és sikeres lebonyolításához. ${ }^{6} \mathrm{~A}$ Vht. a helyszíni eljárás során az ÖBV számára megfelelő eszközrendszert biztosít feladatának elvégzéséhez, illetve - ki kell hangsúlyozni - az eszközrendszer használata nem lehetőség a végrehajtó számára, hanem kötelezettség is egyben. Az ÖBV által lefolytatott helyszíni eljárásról minden esetben jegyzőkönyv készül. A helyszíni eljárási cselekmények foganatosításakor az adósnak - vagy a végrehajtási eljárásban közremüködésre kötelezett személynek, szervezetnek - törvény által elöírt kötelezettségei keletkeznek, mint például a személyazonosság igazolása, az ellenszegüléstől való tartózkodás stb. Amennyiben ezeknek a kötelezettségeknek a megtételét megtagadják, azzal megvalósítják az ellenszegülés tényállását.

„,Vht. 45. § (1) A végrehajtó intézkedésével szembeni ellenszegülés esetén a végrehajtó tájékoztatja az ellenszegülést megvalósitó személyt az ellenszegülés esetén követendö eljárásról és az ellenszegülés következményeiröl, és közvetlenül a legközelebbi, általános rendöri feladatokat ellátó helyi rendöri szervhez fordul, amely köteles a végrehajtási eljárásban haladéktalanul közremüködni az ellenszegülés megszüntetése végett a végrehajtó intézkedésének befejezéséig

6 1994. évi LIII. törvény a bírósági végrehajtásról

43. § (1) A végrehajtás során a végrehajtó megtekintheti és átvizsgálhatja az adós a) lakását és egyéb helyiségét,

b) bármely vagyontárgyát

c) gazdasági tevékenységével kapcsolatos iratait.

(2) A végrehajtás során személymotozásnak nincs helye.

44. § (1) A végrehajtó szǘkség esetén az adós lezárt lakását, a tartozkodási helyeül szolgáló vagy egyèb helyiseget, a hozzajuk vezeto bejâratot, továbbá az adós buttorát vagy más ingoságát felnyithatja. Ha ilyenkor az adós vagy nagykoru csaladtagja nincs jelen, tanút kell alkalmazni. A végrehajtó bármely más eljárási cselekmeny lefolytatásanál is alkalmazhat tanút.

(2) Ha az ingatlan vagy a helyiség felnyitása csak a zár vagy lakat eltávolításával lehetséges, a végrehajtó az új zar, lakat kulcsát az ingatlan fekvesese szerinti rendörkapitányságon helyezi el, ahol azt az adós vagy a vele együtt lakó nagykorú családtagja átveheti. 
(2) Ellenszegülésnek minösül, ha a jogszerü végrehajtói intézkedéssel érintett személy

a) nem veti alá magát a végrehajtói intézkedésnek és fizikai erőkifejtés útján is igyekszik azt megakadályozni, vagy

b) a végrehajtói intézkedés során a számára jogszerüen adott végrehajtói utasitásokat nem hajtja végre, és ezzel akadályozza a végrehajtói intézkedést.

(3) A végrehajtó a rendörség közremüködését a következö adatokkal tünteti fel a végrehajtási cselekményröl készült jegyzökönyvben:

a) intézkedés alá vont személy neve, anyja neve, születési ideje és helye, valamint személyazonositásra alkalmas okiratának száma vagy arra való utalás, hogy ezen adatok megállapítására irányuló intézkedés milyen okból nem vezetett eredményre,

b) a rendöri intézkedés megtételének ténye és az alkalmazott kényszeritö eszköz megnevezése,

c) az ellenszegülés esetén követendö eljárásról és az ellenszegülés következményeiről történö tájékoztatás megtörténte,

d) egyéb lényeges jognyilatkozatok, körülmények.

(4) A rendöri közremüködés jogszabályban meghatározott költségtéritésének összege végrehajtási költség; azt elölegezni nem kell. A végrehajtó a közremüködö rendöri szerv igazolása és a végrehajtási cselekményröl készült jegyzökönyv alapján megállapitja a költségtérités összegét, és az erről szóló jegyzökönyvet kézbesiti a feleknek.

(5) A rendöri szerv az intézkedéstöl számitott 8 napon belül megküldi a költségtérités megállapitásához szükséges igazolást a végrehajtó részére.

(6) A költségtérités behajtott összegét a végrehajtó a közremüködö rendöri szerv székhelye szerinti megyei (fövárosi) rendör-fókapitányság részére fizeti meg. "7

Az ÖBV eljárására, azaz a bírósági végrehajtásra vonatkozóan az 1994. évi XXXIV. törvény a rendőrségről (a továbbiakban: Rtv.) szintén jogszabályi elöírásokat fogalmaz meg a bírósági végrehajtásban közremüködő rendőri állomány számára [Rtv. 33. § (2) d), Rtv. 39. § (1) e), (2)-(3)]. A 30/2011. (IX. 22.) BM rendelet a rendőrség szolgálati szabályzatáról (a továbbiakban: Szolgálati Szabályzat) további közvetlen részletszabályozást is tartalmaz (29. Rendőri közremüködés végrehajtási eljárásban). Itt kerülnek meghatározásra azok a közvetlenül jelentkező feladatok és célok, amelyeket az intézkedés realizációja során a rendőri állománynak figyelembe kell vennie. A jogszabály több rétü feladat és célrendszert határoz meg, amelyek egyrészt az eljárásban résztvevő személyek biztonságának megóvását jelentik, másrészt a kényszercselekményeknek

\footnotetext{
7 1994. évi LIII. törvény a bírósági végrehajtásról.
}

való ellenszegülés megszüntetését célozzák, illetve harmadrészt - amennyiben a végrehajtási kényszercselekményre feljogosított (vagyis az ÖBV) az általános rendőrségi feladatok ellátására létrehozott szerv közremüködését kéri - a személy elleni kényszercselekmények végrehajtását írja elő. Fontos továbbá kiemelni, hogy a bírósági végrehajtás során, amennyiben sürgős kirendelésre van szükség, akkor olyan, legalább két fős járőr vezénylésére van szükség, amelynek vezetőjét a parancsnoki állomány egyik tagja adja, illetve a rendőrnek kell gondoskodnia arról, hogy illetéktelen személyek ne tartózkodhassanak a végrehajtás helyszínén [Szolgálati Szabályzat 37. §. (2)-(3)]. Mint látható a bírósági végrehajtási eljárások során a rendőrség közremüködését tekintve nem kizárólag a rendőrségre közvetlen módon vonatkozó jogszabályi előírások fegyelembe vételére van szükség, hanem magának a rendőri feladathoz kapcsolódó teljes szabályozás ismeretére is. A Vht. a vagyoni kényszer elsődlegességének elve mellett tartalmazza az adós személyiségi jogait érintő kényszer másodlagos (kiegészítő) elvének konkrét előírásait. A rendőrség a bírósági végrehajtási eljárásban a végrehajtási eljárást foganatosító bíróság és az ÖBV intézkedése alapján végzi el a kényszercselekmények realizációját, de a rendőrség eljárását alárendelik a végrehajtás céljának. A rendőri kényszerintézkedések az Rtv. VI. fejezete szerinti formában és mértékben gyakorolhatók. A végrehajtás eredményességének biztosítása, mint cél, intézkedése során köti a rendőrt, de a végrehajtási eljárásban útzár, megállításra kényszerítés alkalmazása is elképzelhető, mint ahogy más személy(ek) elleni kényszerítő eszköz bevetése sem zárható ki (például testi kényszer gyakorlása, bilincs igénybevétele, vegyi eszközök, elektromos sokkoló eszközök stb.). Fontos továbbá kiemelni, hogy a Vht. 222. $\S$ értelmében a végrehajtó és a rendőrség intézkedése elleni jogorvoslatnak nincs halasztó hatálya, tehát erre a helyszíni eljárás realizációja során egyetlen érintett fél sem hivatkozhat.

Főszabály szerint az ÖBV köteles helyszíni eljárást lefolytatni, azaz egy bírósági végrehajtási eljárási elemet kell kötelezö jelleggel foganatosítania. A bírósági végrehajtási eljárási cselekmény foganatosításához az adós jelenléte nem feltétlenül szükséges. Az ÖBV által lefolytatásra kerülő helyszíni eljárásnak több fô célja is lehet, amely célok eléréséhez az ÖBV számára a Vht. biztosítja a jogszabályi kereteket. Az egyik ilyen fö cél az adós tájékoztatása, a másik (a fokozatosság elvének megfelelően) az ingó vagyonelem foglalás alá vonása. (Schadl, 2017) Ki kell emelni, hogy ingó vagyonelem foglalása esetén magának a foglalásnak a megtörténte nem azonos a vagyonelem (kényszer) értékesítésének a jövőbeni megtörténtével. A két időpont elszakad egymástól, illetve az értékesítésre, mint végrehajtási eljárási elemre nem is biztos, hogy sor kerül majd. 
Különböző bűncselekményi tényállások kapcsolódhatnak azon bírósági végrehajtási eljárási elemekhez, amelyek esetleges rendőri helyszíni eljáráshoz kötődhetnek. Az egyik ilyen a Btk. 287. § szerinti zártörés ${ }^{8}$ vétsége, büntette. Ilyen cselekménynek minősül többek között, ha a foglalás alá vont ingó vagyonelemet (például gépjármű) az adós elrejti, az értékesítést megakadályozza, vagy netán harmadik személy részére ő maga értékesíti (az eljárás alól elvonja), de az is megvalósítja a zártörés bűncselekményi tényállását, aki a hatósági eljárás során elrendelt lefoglalásnál, zárlatnál vagy zár alá vételnél alkalmazott pecsétet eltávolítja vagy megsérti, illetve a lefoglalt, zárolt vagy zár alá vett dolog megőrzésére szolgáló, lezárt helyiséget (ingatlant) felnyitja. Az is zártörésnek minősül, ha az elektronikus adat megőrzésére kötelezéssel érintett adatot jogosulatlan személy számára hozzáférhetővé teszik, illetve azt az eljárás alól elvonják vagy módosítják. A zártörés cselekménye látható módon vagyonelemekhez kötődik. A Btk. 288. § szerinti bírósági végrehajtás akadályozása vétsége magatartási formákat von büntetőjogi szabályozás alá. Mindkét büncselekményt csak szándékosan lehet elkövetni. Mindkét esetben a büncselekmény tárgya a végrehajtás zavartalan müködésének, a végrehajtás eredményességének a biztosítása. Mindkét esetben van mód a büntetés elkerülésére, amennyiben szabott határpontig jogkövető magatartást tanúsít az elkövető. A két büncselekmény alapvetően abban különbözik egymástól, hogy a zártörés esetében elkövetési tárgyról (dolog alapú) beszélünk, míg a másik esetben elkövetési magatartásról (tett alapú). További különbséget jelent, hogy a zártörés elkövetője bárki lehet, míg a bírósági végrehajtás akadályozása esetében csak kötelezett személy lehet elkövető (nem kizárólag adós).

\section{Követeléskezelés és behajtás}

A követeléskezelés, illetve köznyelvi, negatív értelemben vett behajtási tevékenység kapcsán úgynevezett követeléskezeléssel foglalkozó gazdasági társaságokról beszélhetünk. Ezek a gazdasági társaságok általában adósságkezeléssel, követelésvásárlással, követelésérvényesítéssel foglalkozó, nyereségérdekelt, polgári jogi alanyokként megjelenő, különböző társasági formában müködő cégek, és ebből a tényből ab ovo következően a kintlévőség kezeléssel kapcsolatos üzleti tevékenységük végzését nem szabályozzák a Vht-ban, az Rtv-ben,

8 614/2002. számú büntető elvi határozat

A végrehajtás alóli elvonással elkövetett zártörés nem eredmény-bủncselekmény, és már azzal megvalósul, ha az elkövetoo a hatóság a lefoglalt dolog feletti rendelkezési, intézkedési jogát időlegesen meghiúsítja [Btk. 249. § (2) bek.]. a Szolgálati Szabályzatban, illetve a bírósági végrehajtás keretrendszeréhez kapcsolódó egyéb jogforrásokban foglaltak. Az ilyen jellegü tevékenység végzésének a közvetett célja - teljesen természetes módon -kizárólag a profit-maximalizálás. (Pataki, 2014) Ezek a gazdasági társaságok az adóssal, kötelezettel szemben nem rendelkeznek semmiféle hatósági vagy hatósági jellegű jogosultsággal. A követeléskezelő, behajtó gazdasági társaságoknak vagy természetes személyeknek semmiféle közhatalmi hatósági jogosítványuk nincs, így semmiféle kényszercselekményt nem alkalmazhatnak sem önállóan, sem a rendőrség közremüködését igénybe véve. Ugyanakkor látni kell, hogy a követeléskezelés, tartozásbehajtás, faktoring tevékenység (nevezzük bárhogyan) a gazdaság minden szegmentumában megtalálható, valamint azt is, hogy normál esetben a követeléskezeléshez köthető tevékenység a gazdaság rendes müködéséhez szükséges, és az ezzel foglalkozók is jogszerüen járnak el. Azonban a hitel-, kötelezettségállomány számosságának és összegszerüségének az általános össztársadalmi szinten tapasztalható növekedése magával vonja ezen gazdasági társaságok piacának növekedését is, így tevékenységük mértéke előre látható módon megnövekszik. Tevékenységüket alapvetően a 2013. évi V. törvény a polgári törvénykönyvről (a továbbiakban: Ptk.) szabályozza. A követeléskezeléssel, követelésvásárlással foglalkozó gazdasági társaságok a Magyar Nemzeti Bank (a továbbiakban: MNB) engedélyével és felügyelete alatt végezhetik tevékenységüket (Lentner, 2018), illetve vonatkoznak még a területre egyéb speciális jogszabályok (például a 2013. évi CCXXXVII. törvény a hitelintézetekről és a pénzügyi vállalkozásokról stb.). Ugyanakkor tudjuk azt, hogy minden egyes követelést lehet engedményezni (a jogosult a követelését szerződéssel másra ruházza), akárhányszor tovább értékesíteni, akár MNB engedélyezéssel vagy MNB felügyelettel nem terhelt gazdasági társaság részére, akár természetes személyek számára is. Egyre gyakoribb az is, hogy az ilyen követelések esetében az adós, kötelezett személyes felkeresése is megtörténik, viszont hiányoznak a bírósági végrehajtást szabályozó jogi normatívák. A gyakorlatban egyre gyakrabban tapasztalható, hogy a tényleges müködés során nem érvényesül a felügyeleti jogkör, mert az engedélyes cég kifejezetten sok alvállalkozót és egyéb más céget alkalmaz, azaz követelésvásárlás és engedményezés történik a jogutódok sorára, amelyek természetesen minden további nélkül felszámolhatók probléma esetén.

A Budapesti Kereskedelmi és Iparkamarán belül létrejött a Követeléskezelö Szakmai Osztály, ahol 2011 novemberében aláírásra került egy Magatartási Kódex, amely a Követeléskezelő társaságok a lakosság részére hitelt nyújtó pénzügyi intézmények nem problémamentes ügyleteinek kezelésével kapcsolatos tisztességes piaci magatartásáról címet viseli, és mindösszesen 10 oldal 
terjedelemben határozza meg a követendő általános elveket ${ }^{9}$, de természetesen maga a Magatartási Kódex jogi kötőerővel nem rendelkezik.

Evidenciaként jelentkezik ugyanakkor, hogy a tartozás behajtással, követeléskezeléssel foglalkozó gazdasági társaságok profitorientált tevékenységet végeznek, és ebböl következik az a tapasztalati faktum is - tisztelet a kivételnek -, hogy üzleti tevékenységük realizációja kapcsán nem minden esetben veszik figyelembe a morális társadalmi normákat és a jogi szabályozókat - hiszen a morál nem üzleti kategória, a jog megsértése pedig csak bizonyítást nyert esetben szankcionálható -, így az általuk alkalmazott módszerek erkölcsi alapjai is nem ritkán megkérdőjelezhetők ${ }^{\mathbf{1 0}}$ (a gazdasági alapjai nem, hiszen azok a tulajdonos, a cégvezetés elvárásain, döntésein alapulnak). A behajtó, követeléskezelő cégek tevékenysége mindezen túlmenően nem biztosítja az érdekelt felek számára a teljes körü (sőt néha semmiféle) jogorvoslat igénybevételének lehetőségét, eljárásukhoz pedig nem tapadnak tételesen meghatározott törvényi garanciák, hiszen más a szemléletmód, ami természetesen nem jelenti azt, hogy az egyes vonatkozó jogszabályi elöírásokat ne kellene betartaniuk. Az orientációt rossz esetben a mindent szabad, amit törvény nem tilt mottóval jellemezhetjük. Többnyire egyéni, adott eseti ügy szerinti megkeresések alapján (nem azonos a bírósági végrehajtó által foganatosított helyszíni eljárási cselekménnyel) próbálnak eredményt (a követelés végrehajtása és kielégítése tekintetében) elérni.

Természetesen a követeléskezelés, behajtás esetében is beszélni kell különböző büncselekményi tényállásokról, amelyek esetleges rendőri eljáráshoz kötődhetnek. A Btk. 221. § által szabályozott magánlaksértés ${ }^{11}$ tényállása lehet az egyik

9 BKIK Magatartási Kódex 1. o

„A Követeléskezelöknek a tevékenységüket úgy kell végezniük, hogy mindeközben biztositsák, hogy a Hitelintezzetek megtérülese minél nagyobb legyen, és ezen keresztül a betétesek pénze minél nagyobb gitenek az Adósoknak azzal, hooy olyan megoldási javaslatokat dolgoznak ki és ajánlanak fel, amelyek gitenek az Adosoknak azzal, hogy olyan megoldasi javaslatokat dolgoznak ki es ajanlanak fel, amelyek
célja, hogy a jelzálog fedezetü hitelesek és más Adósok megsegitésére létrehozott jogszabályok feltétecelja, hogy a jelzälog fedezetú hitelesek és mäs Adosö megsegitésére létrehozott jogszabalyok feltéte-
leinek betartása mellett az Adósok ingatlana ne kerüljön végrehajtásra, és a Követeléskezelók lehetóség szerint olyan törlesztó részleteket alakitsanak ki és ajánlanak fel, amit az Adósok teljesiteni is tudnak."

10 Természetesen az ilyen jellegủ tevékenységgel foglalkozó gazdasági társaságok többsége a vonatkozó jogszabályi elöirasoknak megfelelöen müködik és eljárásuk minden tekintetben jogszerünek tekinthetỏ. Az itt megfogalmazottak természetesen nem vonatkoznak ezekre a gazdasági társaságokra. Kizárólag elméleti problémafelvetés került elemzésre, illetve az ebben a cikkben leírtak nem vonatkoznak egyetlenegy természetes, vagy jogi személyre, ill. jogi személyiség nélküli társaságra sem közvetlen, vagy

Magyarorszáa Alaptörvénye

VI cikk (1) Mindenkinek joga van ahhoz, hogy magán- és családi életét, otthonát, kapcsolattartását és kezési jog gyakorlása nem jarhat mások magan-és családi életének, valamint otthonának sérelmével.

(2) Az allam jogi védelemben részesiti az otthon nyugalmát.

(3) Mindenkinek joga van személyes adatai védelméhez, valamint a közérdekü adatok megismeréséhez és terjesztéséhez.

(4) A személyes adatok védelméhez és a közérdekü adatok megismeréséhez való jog érvényesülését sarkalatos törvénnyel létrehozott, független hatóság ellenörzi. ilyen tipikus módon kapcsolódó cselekmény. A magánlaksértés esetében fontos kiemelni azt, hogy a büncselekmény jogi tárgya a lakás, egyéb helyiség és az azokhoz tartozó bekerített hely lehet. Nem csak a jogosulatlan bemenetellel vagy bennmaradással valósítható meg, hanem azzal is, ha a jogosultat meggátolják a bemenetelben vagy a kijövetelben. Sajátos eset lehet, ha a követeléskezelő, behajtó hivatalos színben tünteti fel magát (például ÖBV-nek). További általános tény, hogy a követeléskezelö, behajtó az úgynevezett kiskapukat rutinszerüen igyekszik kihasználni, míg a sértettnek nincs megfelelő tudása vagy tapasztalata az ilyen kérdésekben, így joggal várja el a rendőrségtől a szakmai hozzáértést és a megfelelő tájékoztatást. További kapcsolódó tényállás a Btk. 222. § zaklatás vétsége ${ }^{12}$. Ebbe a körbe tartoz(hat)nak a sorozatos személyes felkeresések, a sorozatos telefonhívások stb. Közvetlenül kapcsolódhat továbbá (például az engedményezések kapcsán) a Btk. 223. § által leírt magántitok megsértésének alakzata. Mivel a fenti büntetőjogi tényállások elkövetője kizárólag magánindítvány esetén büntethető, ezért további fontos elem az elkövető személyének ismerete ${ }^{13}$, mert ennek hiányában a sértett a joghoz fordulás lehetőségét elveszíti.

\section{Adatvédelem, adatkezelés}

Az ÖBV a részére nyújtott törvényi felhatalmazás alapján gyüjt és kezel olyan adatokat, amelyek a személyes adatok ${ }^{14}$ körébe tartoznak, és teszi mindezt az adatgyüjtés és az adatkezelés célhoz kötöttsége alapelvének betartásával, hi-

12 BH2016. 261. A zaklatás Btk. 222. § (1) bekezdésében írt esete szubszidiárius büncselekmény, ezért ha a zaklató magatás egyben gá́z pítani A jogellenes cselekmény csak akkor minősül szubszidiárius bủncselekménynek, ha más, súlyosabb büncselekmény nem valósul meg. A szubszidiárius bủncselekmény alternatív jellegú büncselekmény: buncselekmeny nem valósul meg. A szubszidiárius büncselekmény alternatív jellegú búncselekmény: ütközik, akkor nem a szubszidiárius büncselekményt állapítják meg, hanem a másik büncselekményt. 13 BH2018. 216

I. A magánindítvány előterjesztése az elkövetö kilétének ismeretéhez kötött. Az ismeretlen személy ellen előterjesztett magánvád nem törvényes, a bíróság eljárásának alapját nem képezheti. Azonban a magánindítvány előterjesztésére jogosult sértett bármelyik elkövetővel szemben előterjesztett magánindítványa valamennyi elkövetővel szemben hatályos. İgy a magánindítvány joghatályos a közvetett tettessel szemben is, ha az eljárás későbbi szakaszában derül ki: az abban megjelölt elökövető tévedés miatt nem büntethetó, azonban a közvetett tettes igen [2012. évi C. tv. 31. § (5) bek., 1998. évi XIX. tv. 173. \& (3) bek.].

14 20/1990. (X. 4.) AB határozat

A magantitok es a személyes adatok védelméhez való jog tartalma, hogy mindenki maga rendelkezik magantitkainak és szemèlyes adatainak feltárásáról és fehlasználásáról. A vagyonra vonatkozó adatok az ember magantitkat képezik ess szemelyes adatânak minosuulnek. A maganntitok és a személyes adatok védelméhez való jog törvényi korlátozása csak abban az esetben minosithetó alkotmányosnak, ha megfelel az Alkotmányban a korlátozásokkal szemben támasztott követelményeknek. 
szen az adatgyüjtés és adatkezelés rá, mint a bíróság hatáskörében eljáró adatkezelöre, a vonatkozó kötelezettségeinek teljesítése céljából szükséges eljárási elemek sorozata, valamint egy harmadik személy (végrehajtást kérö) jogos érdekének érvényesítése céljából szükséges. A 2011. évi CXII. törvény az információs önrendelkezési jogról és az információszabadságról (a továbbiakban Info tv.) 3. § 2. pontja kimondja, hogy személyes adatnak minősül az érintettre ${ }^{15}$ vonatkozó bármely információ. Az Info tv. szerint adatkezelésnek minősül - az alkalmazott eljárástól függetlenül - az adatokon végzett bármely müvelet vagy a müveletek összessége (például gyüjtés, rögzítés, rendszerezés, tárolás, megváltoztatás, felhasználás, továbbítás stb.). A jelen esetben alapvetően követelésekkel (polgári jog) kapcsolatos adatkörről beszélhetünk (úgy, mint személyes adatok, gazdasági adatok, tulajdonnal, birtoklással, jogügyletekkel kapcsolatos adatok, adatkezelés, adatfeldolgozás, adattovábbítás stb.).

A követeléskezelés esetében az engedményezések során adatgyüjtés és adattovábbítás történik. A jogutódok számának növekedésével egyre kétségesebb lehet az adatkezelések jogszerüsége. A Nemzeti Adatvédelmi és Információszabadság Hatóság (a továbbiakban: NAIH) több határozatában kimondta, hogy több követeléskezelő gazdasági társaság is több esetben jogellenes adatkezelési tevékenységet folytatott, mert megszegte az elözetes tájékoztatási kötelezettségét, a tisztességes és a célhoz kötött adatkezelés elvét, és jogalap nélküli adatkezelést folytatott, továbbá megtiltotta számukra a személyes adatok jogellenes kezelését ${ }^{16}$, valamint az érintett gazdasági társaságokat adatvédelmi bírság megfizetésére kötelezte. A NAIH már a 2014-ben

15 Az Európai Parlament és a Tanács 2016. április 27-i (EU) 2016/679 Rendelete a természetes személyeknek a szemelyes adatok kezelése tekintetében törtenô védelméról és az ilyen adatok szabad áramlásáról, valamint a 95/46/EK irányelv hatályon kívül helyezéséröl (általános adatvédelmi rendelet) 4. ciḱtható természetes személyre (érintett) vonatkozó bármely információ; azonosítható az a természetes személy, aki közvetlen vagy közvetett módon, különösen valamely azonosító, például név, szám, helymeghatározó adat, online azonositó vagy a természetes személy testi, fiziológiai, genetikai, szellemi, gazdasági, kulturális vagy szociális azonosságára vonatkozó egy vagy több tényezỏ alapján azonosítható.

2011. évi CXII. törvény az információs önrendelkezési jogról és az információszabadságró 3. § E törvény alkalmazása során:

1. erintett: barmely információ alapján azonosított vagy azonosítható természetes személy. 1a. azonosítható természetes személy: az a természetes személy, aki közvetlen vagy közvetett módon, különösen valamely azonosító, például név, azonositó szám, helymeghatározó adat, online azonosító vagy egy, vagy több tényezo alapjan azonositható.

16 Vö. NAIH/2016/5616/H., NAIH/2017/935/5/H., NAIH/2017/936/5/H., NAIH/2017/1051/2/H., NAIH/2017/3887/H., NAIH/2018/698/5/H.

Vö. Fővárosi Közigazgatási és Munkaügyi Bíróság 28.K.30.283/2016/42., Fővárosi Közigazgatási és Munkaügyi Bíróság 5.K.31.249/2017/5., Kúria Kfv.III.37.801/2017/6. ajánlást ${ }^{17}$ bocsátott ki a követeléskezelés, tartozásbehajtás, adósságbehajtás, faktoring tevékenység során alkalmazott követeléskezelési technikák adatvédelmi követelményeiről a hatalmas mértékü kezelt összeg, a magas ügyszám és a tapasztalt hiányosságok okán. 2014 óta az adatvédelem területén [köszönhetően az Európai Parlament és a Tanács 2016. április 27-i (EU) 2016/679 rendeletében foglaltaknak] az adatvédelemre vonatkozó jogszabályi környezet megváltozott. A követeléskezeléssel. behajtással érintett ügyek száma nem csökkent. Napjainkban még csekély számú bejelentés érkezik a NAIH-hoz, de ez a szám is kétségkívül növekedni fog, és amennyiben a NAIH szabálytalanságot állapít meg határozatában bizonyosan különböző büncselekményi tényállások is előtérbe kerülnek majd.

\section{Felhasznált irodalom}

Balogh O. - B. Korek I. - Császti F. - Juhász E. - Sáriné Simkó Á. (2009) (szerk.): A bírósági végrehajtás. Budapest: HVG-ORAC Lap- és Könyvkiadó

Földi A. - Hamza G. (2007): A római jog története és institúciói. Budapest: Nemzeti Tankönyvkiadó

Frank I. (1846): A közigazság törvénye Magyarhonban II. rész. Buda: Magyar Királyi Egyetem Harmathy A. (1989): A tulajdonjog alkotmányos védelme. Jogtudományi Közlöny, 5, 217-228.

Kapa M. (2006): Hitelezővédelem a birósági végrehajtásban. Budapest: Dialóg Campus Könyvkiadó

Kovács I. (1989): Magyar államjog II. Szeged: JATE Kiadó

Lentner Cs. (2017): Kormányzati és közigazgatási feladatok közgazdasági és közpénzügyi megalapozása. Budapest: Nemzeti Közszolgálati Egyetem

Pataki J. I. (2013a): A végrehajtó és az adós. Budapest: Ad-Librum Kiadó

Pataki J. I. (2013b): Gondolatok birósági végrehajtás rendszeréröl. Jogelméleti Szemle, 1, 121-135.

Pataki J. I. (2014a): A bírósági végrehajtás-behajtás ellentétpárról. Jogelméleti Szemle, 2, 216-226.

Pataki J. I. (2014b): Adalékok a birósági végrehajtáshoz a római jogban. Acta Universitatis Sapientiae Legal Studies, 2, 139-152.

Pokol B. (2000): Jogi alaptan. Budapest: Rejtjel Kiadó

17 NAIH Ajánlás

1993-ban jott létre a Magyar Koveteléskezelők és Üzleti Információ Szolgaltatók Szōvetsége (a továbbiakban: MAKISZ). A Magyar Faktoring Szövetség 2003 közepen alakult. A MAKISZ statisztikai adatai szerint tagjai 2012-ben több mint 1100 milliảrd forint ertekben kezeltek követelesállomanyt, amelyet közel 14 millió ügy testesített meg. 
Schadl Gy. (2017): Az ingófoglalás alapvető szabályai a birósági végrehajtási eljárás során. Polgári Szemle, 1-3, 83-93.

Téglási A. (2008): A tulajdonhoz való jog alkotmányos védelme - Történeti áttekintés. De iurisprudentia et iure publico, 4, 67-133.

Vida I. (1978): A birósági végrehajtás. Budapest: Közgazdasági és Jogi Könyvkiadó 